\title{
Cooperative Learning Environment in Teaching Mobile Application Development
}

\author{
Antonio Márcio Albuquerque Almeida* \\ *Departamento de Engenharia da Computação, Universidade Federal do Ceará, Sobral, Brazil. \\ E-mail: marcio.albu@alu.ufc.br \\ Leonardo Pires De Sousa Silva \\ •Departamento de Engenharia Elétrica, Universidade Federal do Ceará, Sobral, Brazil. \\ E-mail: leonardopires85@hotmail.com \\ Francisco Heitor Vasconcelos \\ `Departamento de Engenharia Elétrica, Universidade Federal do Ceará, Sobral, Brazil. \\ E-mail: fheitorvasconcelos2@gmail.com \\ Rômulo Nunes De Carvalho Almeida ' \\ 'Departamento de Engenharia Elétrica, Universidade Federal do Ceará, Sobral, Brazil. \\ E-mail: rnunes@dee.ufc.br
}

\begin{abstract}
The evolution of techniques in technological vocational education constitutes a series of pedagogical strategies that allow learning, exercise, incentive and practice for students. The interdisciplinary projects in the University aims to assist the individual in learning with the incentive of activities directed for collaborating with students in undergraduate. These projects are important for undergraduate courses in Electrical Engineering and Computing Engineering at the Universidade Federal do Ceará (UFC), Sobral campus. This article presents a case study developed by our project called Cooperative Learning Cell for The Development of Android Applications, applied in
\end{abstract}


groups of Engineering students in the first and second semesters, using recent teaching methods aimed at learning, occurring in the period from September to December 2016. The main objective of the project was to encourage the student to learn, achieve academic growth and promote the learning and sharing of knowledge about the programming content for mobile devices, aimed at the Android operating system. In addition, it seeks to stimulate the student with more interactive content, applying examples and activities related to mobile programming that were related with the content of the Engineering course or the labor market. After the group of students was created, nine meetings took place. In each of them, the cooperative learning methodology was applied to the group, where the knowledge was generated through the interaction between two or more people, resulting in an active participation of the educational process. The classes were designed with a focus on content exposure, challenges and small projects to solve group tasks. In addition, professionals working in Engineering companies in the northern region of Ceará were invited to give lectures to show the current situation of the labor market, focused on mobile applications. The project and student evaluation was done in an interactive way, through questionnaires, evaluating the results and interests of the students relative to the activities proposed during the course period.

Keywords: Educational Incentive, Cooperation, Engineering Education, Teaching Mobile Application, Android.

\section{Introduction}

The lack of encouragement to students constitutes is one of the major problem for the educational environment ${ }^{1}$, surveys show that students arrive increasingly unmotivated in the Universities, with issues such as dismissals in disciplines and a high rate of evasion ${ }^{2}$. To have an appropriate education environment it is necessary to consider the three types of variables: the environment (family, school and the social environment); The internal forces of the individual (need, desire, will, interest, impulse and instinct); Object that attracts the individual by being source of satisfaction of the internal force that mobilizes him $^{3}$. Analyzing Graphic 1, Graphic 2, Graphic 3 and Graphic 4, the indices of disapprovals for the 2016.1 and 2016.2 semesters (data collected by the coordination of Electrical Engineering and Computing Engineering, from Universidade Federal Ceará, Sobral campus, through the Integrated System of Academic Activities Management (SIGAA) ${ }^{4}$, analyzing the academic period 2016.1 for the course of Computing Engineering, these initial disciplines had the total of 249 disapprovals, considering all the disciplines of this academic period, got a total of 450 disapprovals. With these data it was observed that $63 \%$ of the disapprovals occur in the basic formation cycle (the first two semesters of the course). And the following semester, 2016.2 in the numbers of disapprovals have suffered a reduction, but the disapprovals rate for the initial semesters is still above $50 \%$. These data are also no different for the Electrical Engineering course.

Several factors may have been the cause of these high rates, one of them may be the lack of motivation for the student. If the motivation originates in the desire to satisfy a necessity, there is no need, there will be no motivation. On the contrary, the normal reaction of the person, when compelled to an activity not resulting from a desire to satisfy a necessity, is the demotivation ${ }^{5}$. 


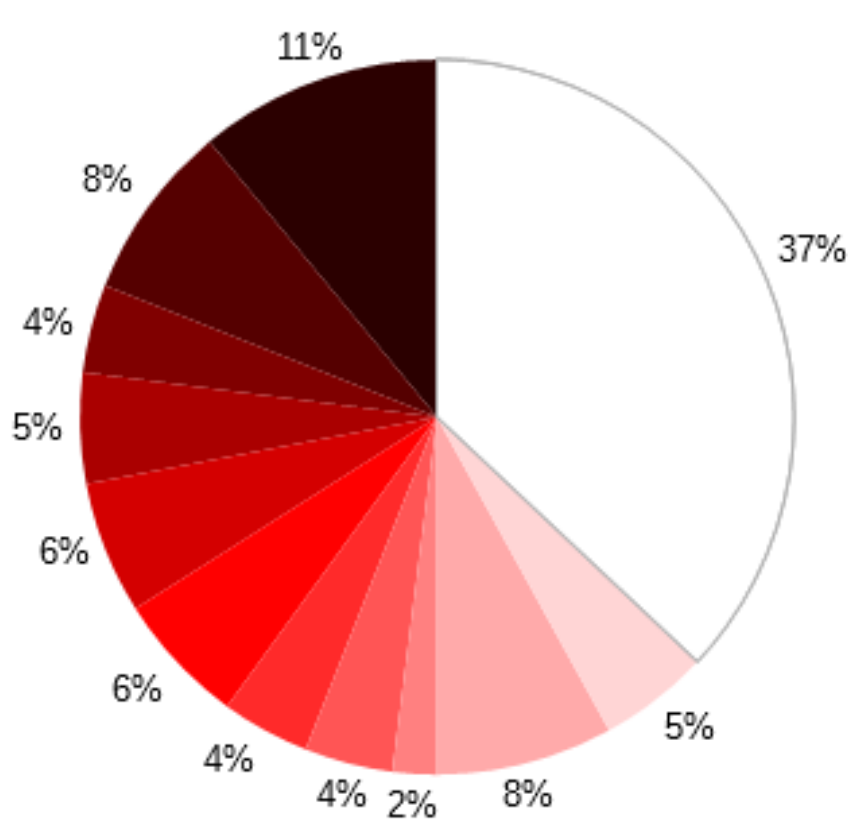

- Physics I

- Differential and Integral Calculus I

- Introduction to Engineering

$37 \%$ Discrete Mathemathics

- Computer Programming

- Physics II

- Differential and Integral Calculus II

Engineering Drawing

= Programming Technique

a Probability and Statistics

Linear Algebra

$\square$ Other Disciplines

Graphic 1. Disapproval data for the first semester of Computer Engineering.

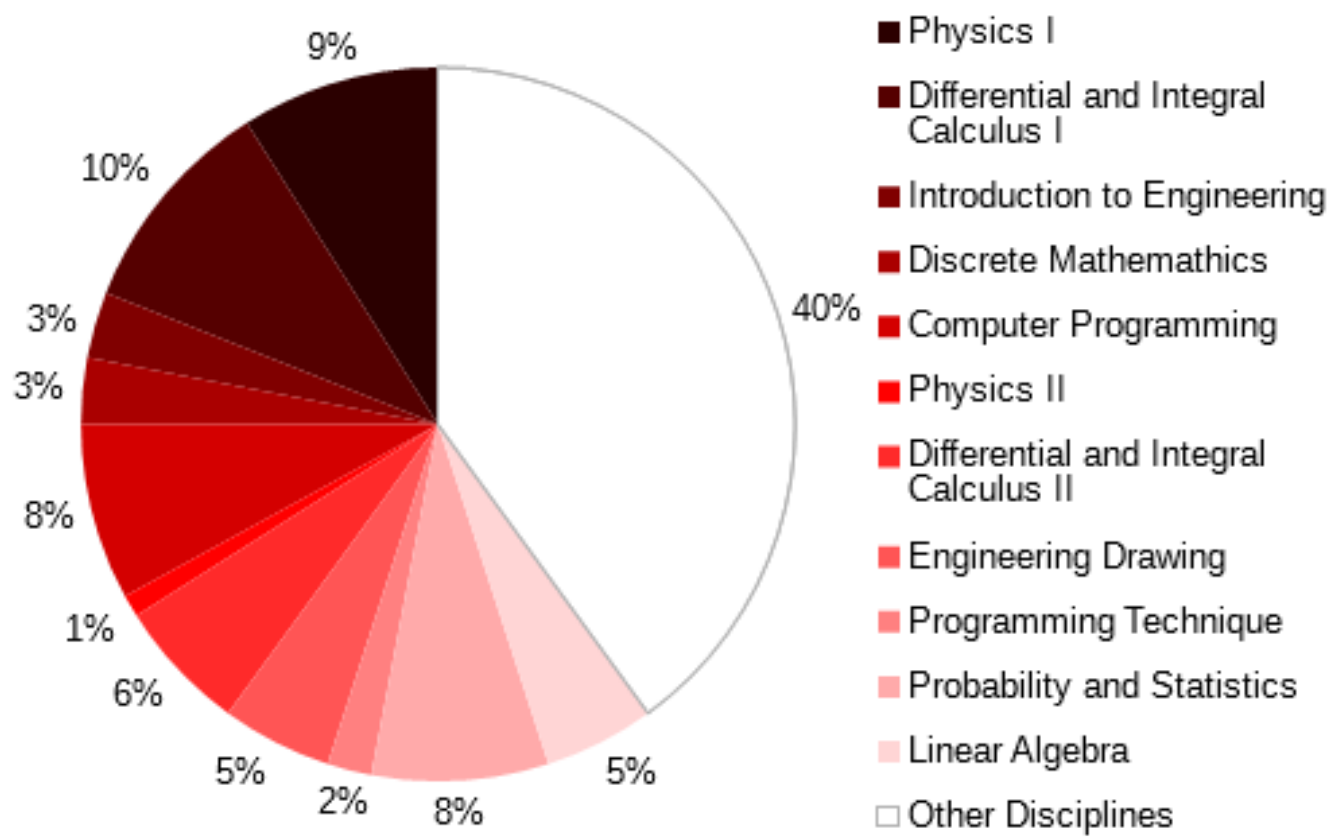

Graphic 2. Disapproval data for the second semester of Computer Engineering. 


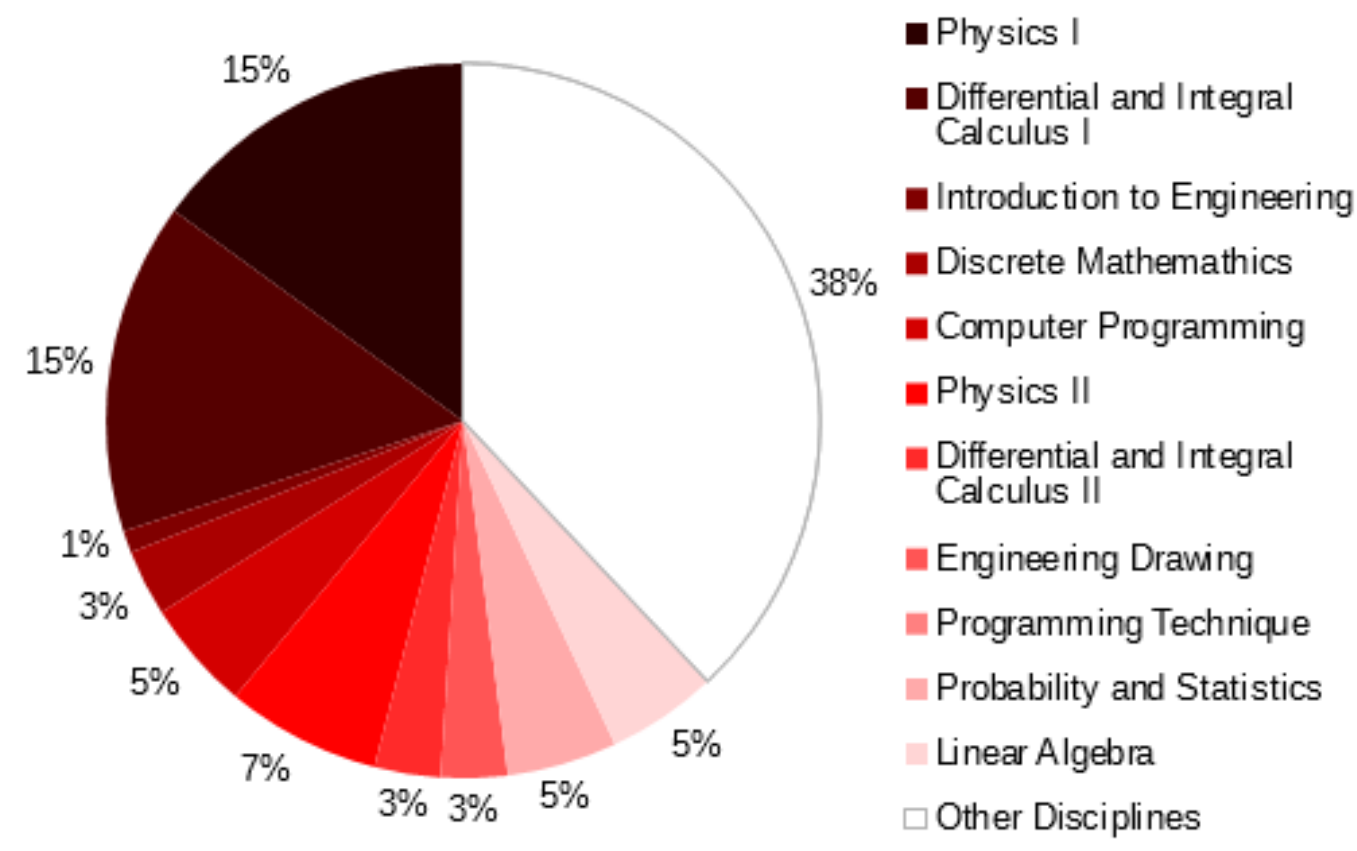

Graphic 3. Disapproval data for the first semester of Electrical Engineering.

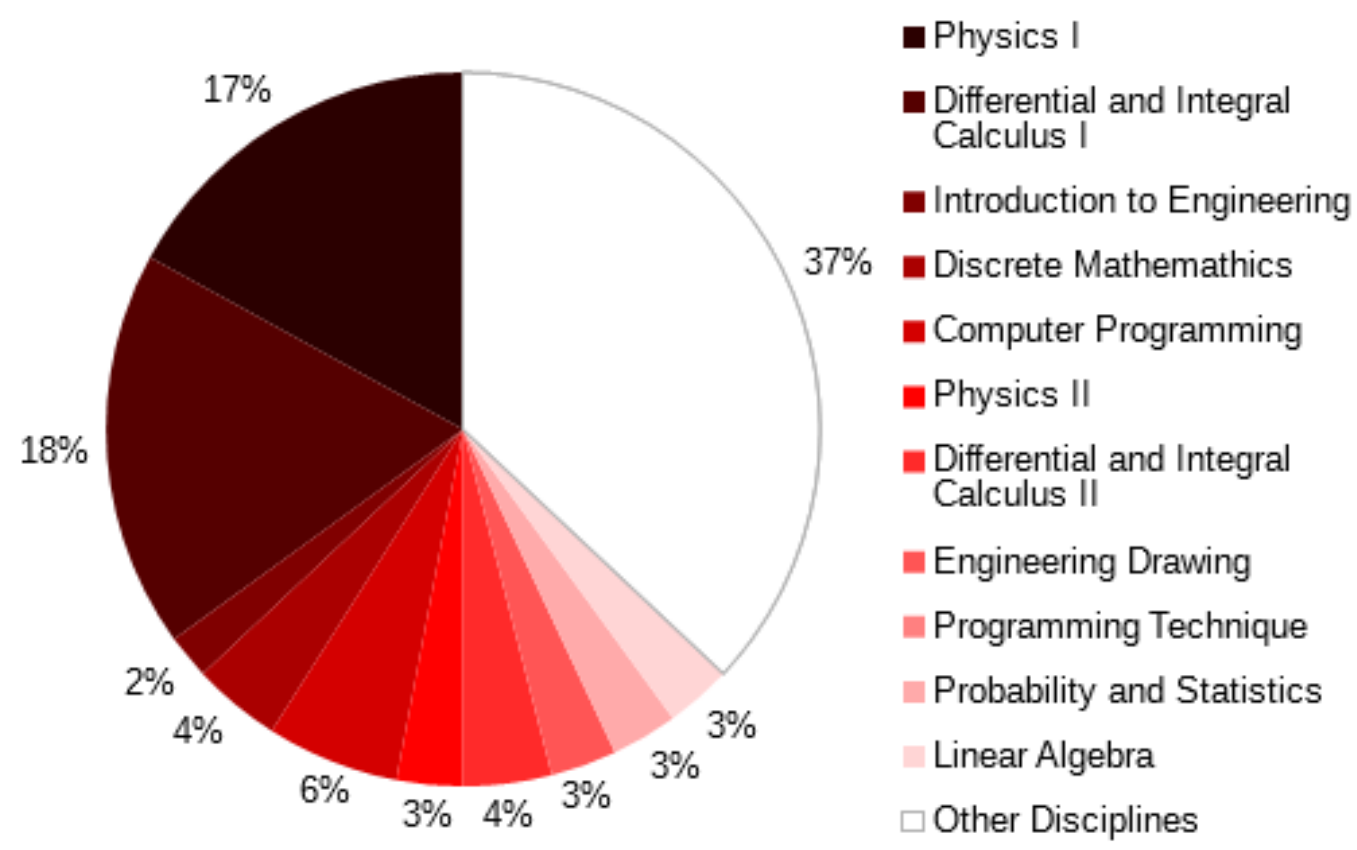

Graphic 4. Disapproval data for the second semester of Electrical Engineering. 
With the emphasis on this problem, the Federal University of Ceará promotes programs based on the Methodology of Cooperative Learning, in order to encourage students ${ }^{6}$. The concept of Cooperative Learning, applying for high-positive interdependence, i.e. students perceive that they can attain their learning targets if, and only if, all members of their group also achieve. In Cooperative Learning knowledge is built by the instructor and the students in a dynamic process. The active participation of the student is fundamental in the work group and the deliberate formation of the team must prioritize small teams (2-4 members). The staff always checks the quality of their work and how the members are working ${ }^{7}$.

One of these programs promoted by the University is the Cooperative Learning Cell for Android Application Development ${ }^{4}$, that aims to promote learning and knowledge sharing for Engineering students from the first and second semesters of the Sobral campus. With the use of new educational subjects, focused on the professional and academic environment, in the mobile programming area, for Android operating system.

\section{Methodology}

The project had the collaboration of four members, which had as a function of the organization and cooperation with the students. A wide dissemination of the project was done through social networks, distribution of pamphlets and also with the dissemination in classrooms. It was clarified previously how would be the organization of the meetings of the group, passed on the certain subjects that would be discussed in the meetings.

In the first step, a selection of the participants was made through a questionnaire in which the student answered personal information. One of the essential questions was about the student's motivation to participate in the group. The four organizing members evaluated the questionnaires and chose the participants, considering the criterion of interest to participate ${ }^{8}$, at the end of the process was totalized 21 members. Photograph 1 shows the first meeting in the computer lab space of the University.

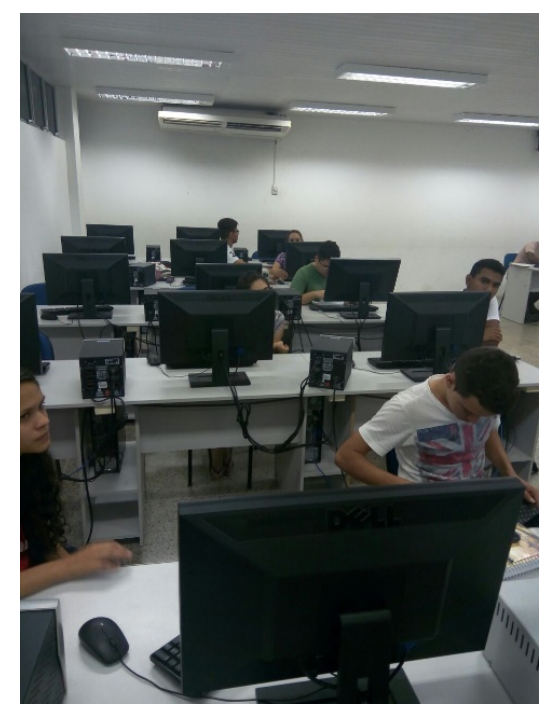

Photograph 1. First meeting of the group.

In this meeting the project was clarified: schedules, books and software used (Java SE Development Kit, Netbeans, Android Studio $)^{9}$. It was also pointed out that the hours of 
the certificates (issued at the end of the course) would be based on the frequency of the students in the group meetings. One of the important elements has been clarified since the disclosure, the mode of class structures. It was defined in two moments: distance educations and live class.

At the first moment classes were held through social media, sending content related to the subject of Android programming or related information ${ }^{10}$. This idea was applied in the form of bringing something new to the group, strengthening studies on the theme, in moments beyond the meeting time. This medium was also used to distribute meeting materials. Always demonstrating an equal student-instructor interaction, for better conviviality. Already in the second moment were the class in the laboratory, in which began with Java (programming language) to introduce the subject, which always followed a structure: content transmission, applications of examples and challenges, which were based on the resolution of content related with those presented in class. In Android programming classes we taught Logical Operations, Arithmetic, Decision Structure, Graphical Interface, among others. Always focusing on interdisciplinary, connected disciplines of Physics, Mathematics and Programming.

Showing practical examples like creating a calculator with basic arithmetic operations. We applied exercises on how to create a user application and password to be able to enter other functions of the application, in this way, we worked the sensorial dimension of the information perception process, since the subjects learned the concepts and solved an application that involved the Content. In Figure 1 was one of the activities passed on to students involving mathematical knowledge to determine whether number is odd or even by applying the mathematical concepts of Equation 1 and 2 to the proposed program logic of the application.

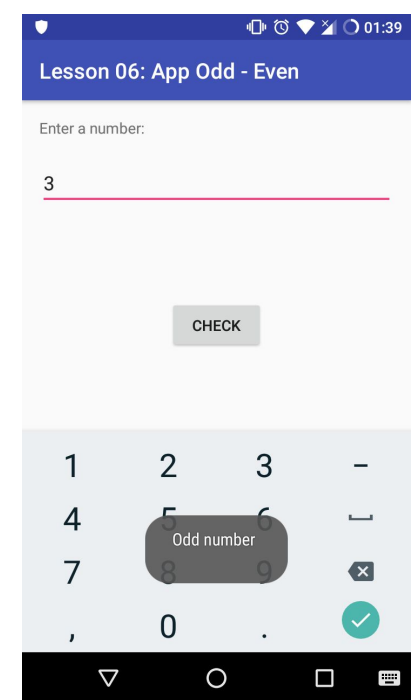

Figure 1. Activity for application development Odd/Even.

$$
\begin{aligned}
& E=\{x \in \mathbb{Z} \mid x=2 y, y \in \mathbb{Z}\} \text { and } \\
& O=\{x \in \mathbb{Z} \mid x=2 y-1, y \in \mathbb{Z}\},
\end{aligned}
$$


where $\mathrm{O}$ and $\mathrm{E}$ represent the result if the number is odd or even respectively, $\mathrm{x}$ is the value of the integers $(\mathbb{Z})$ received and $\mathrm{y}$ is the value of the result of the equation to be checked if it still belongs to the values of the integers $(\mathbb{Z})^{11}$.

Furthermore, lectures in which organized where the students had the opportunity to talk and ask questions to professionals in the fields of Electrical Engineering and Computing on the labor market. Here we opted to work the intuitive, reflective and active dimensions of the learning process, in this sense, the student can create relationships and identify the operationalities of the subjects studied, and reflect on the possibilities through the area of study addressed, considered the labour market in the region, so the student can assign new senses to undergraduate in Engineering and its areas of expertise. Photograph 2, student of Computing Engineering and employee of the company Ware, reviewing experiences and difficulties with Android programming for students of the group.

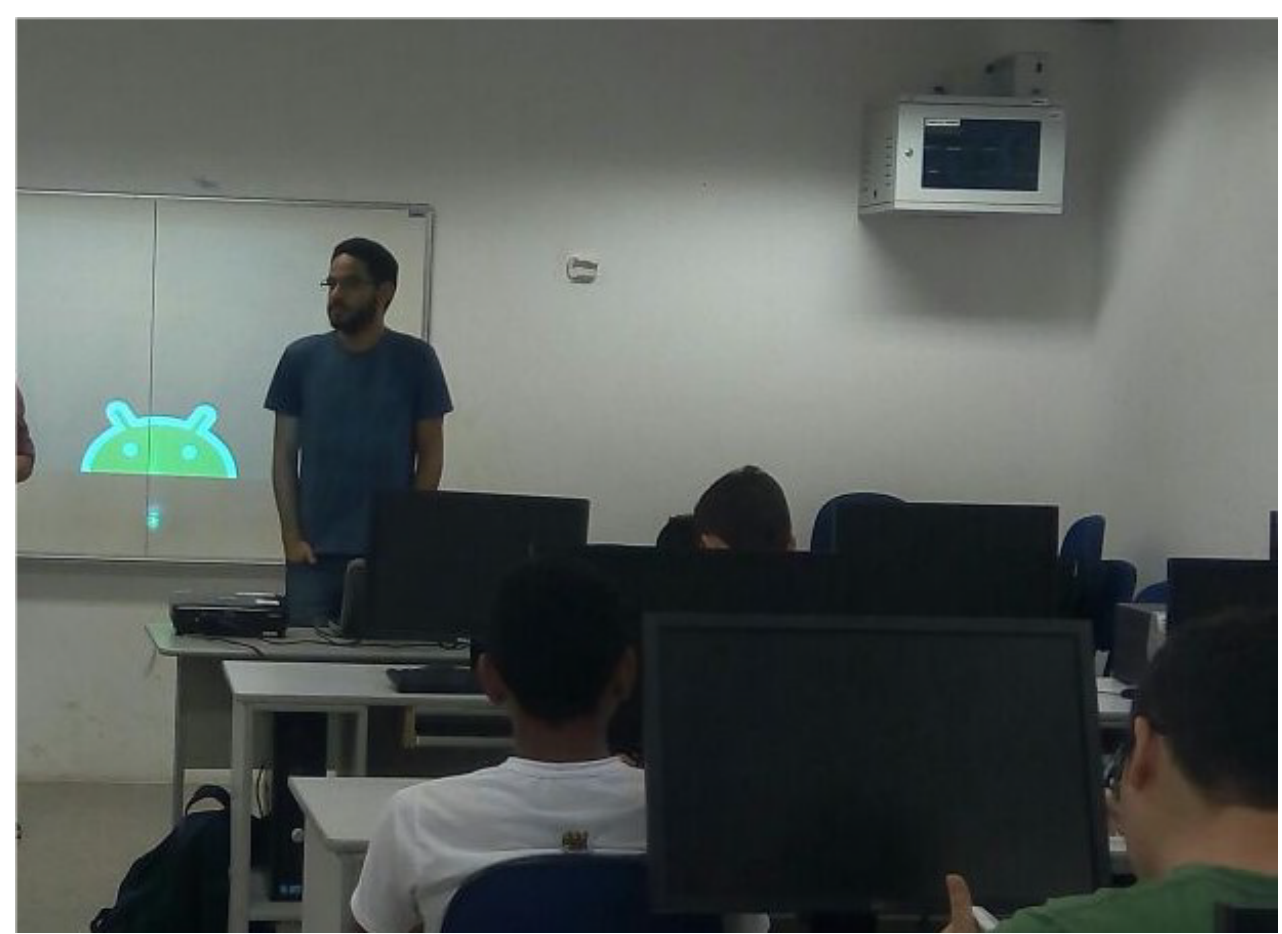

Photograph 2. Lecture about Android programming.

\section{Results}

In total, nine meetings took place in the period from September to December 2016. During the project there was a dropout rate of approximately $24 \%$ of participants. To evaluate the results, a questionnaire was developed to measure the level of interaction and learning development of the participating students. The questions were made available to project participants through the online form tool.

The questionnaire was divided into four sections, such as the programmatic content for the classes, the physical space where the meetings took place, the student's development (self- 
evaluation) and also the instructors, respectively. Each section consists of a set of objective questions, so it is possible to draw conclusions about the impression and impact of the project.

The Graphic 5 and the Graphic 6, show an average rate for the set of questions about the programmatic content and the physical space, respectively.

The teaching model and the structure adopted in the programmatic content reached a great acceptance in the group. Analyzing the data of the physical environments, it was not of total pleasure to the members of the group, one of these possible causes was the fact that the laboratory does not have computers with good.

In the third section of questions a self-assessment was carried out with the students. They were asked about attendance, interest in Android programming, participation during classes and compliance with the activities proposed by the instructor. In the fourth section the students had the opportunity to evaluate the instructor and teaching methodology applied during the course, Cooperative Learning. In this section, the student could evaluate if the instructor used didactic techniques favorable to the fixation of the material, clarified the doubts of the students, was objective in his explanations and encouraged and provided a favorable climate for student participation.

The Graphic 7 and the Graphic 8, shows an average rate for the set of questions about student self-assessment and group assessment, respectively.

The average level of interest in Android programming before the course was $63 \%$ while $25 \%$ had a vague interest in the subject. Regarding the instructors, an average of $92 \%$ of the students indicated that the content was passed on with confidence and that didactic tools were used that collaborated to teach and fix the presented content. In addition to pointing out that their doubts were satisfactorily clarified by the instructors.

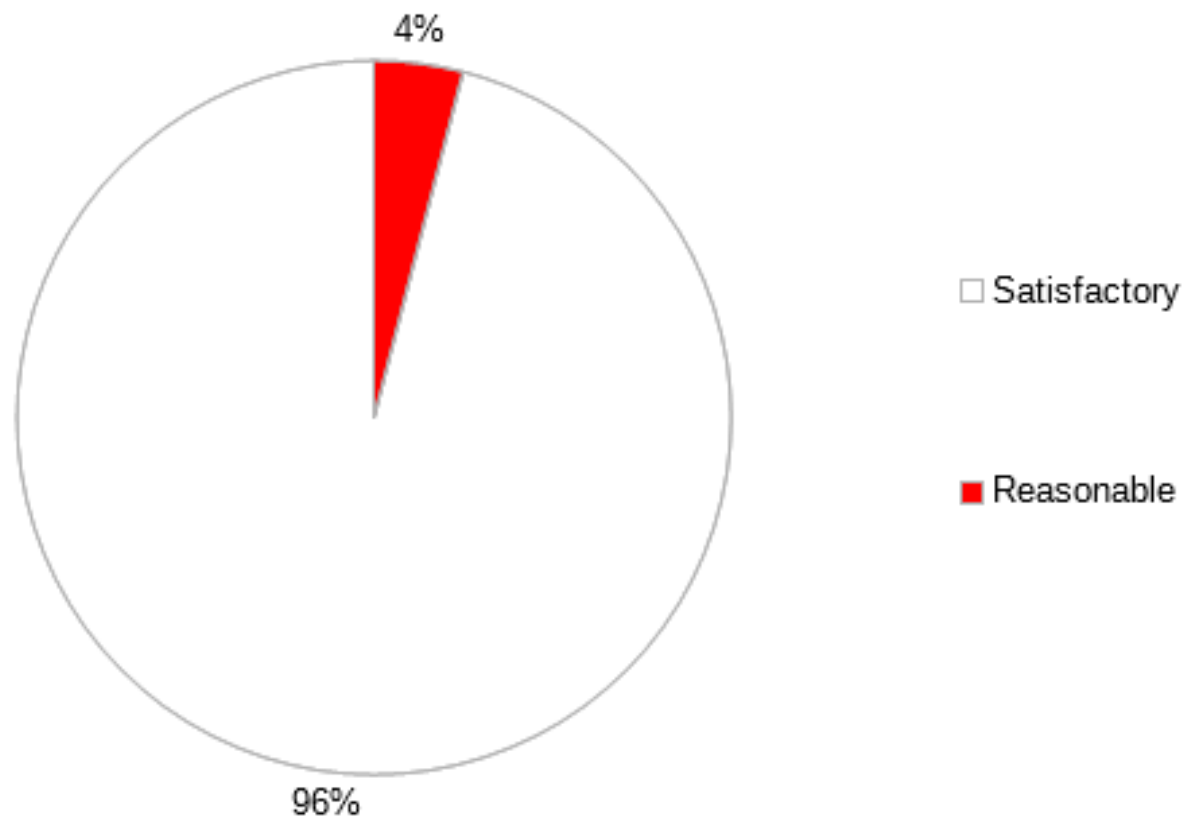

Graphic 5. Programmatic content. 


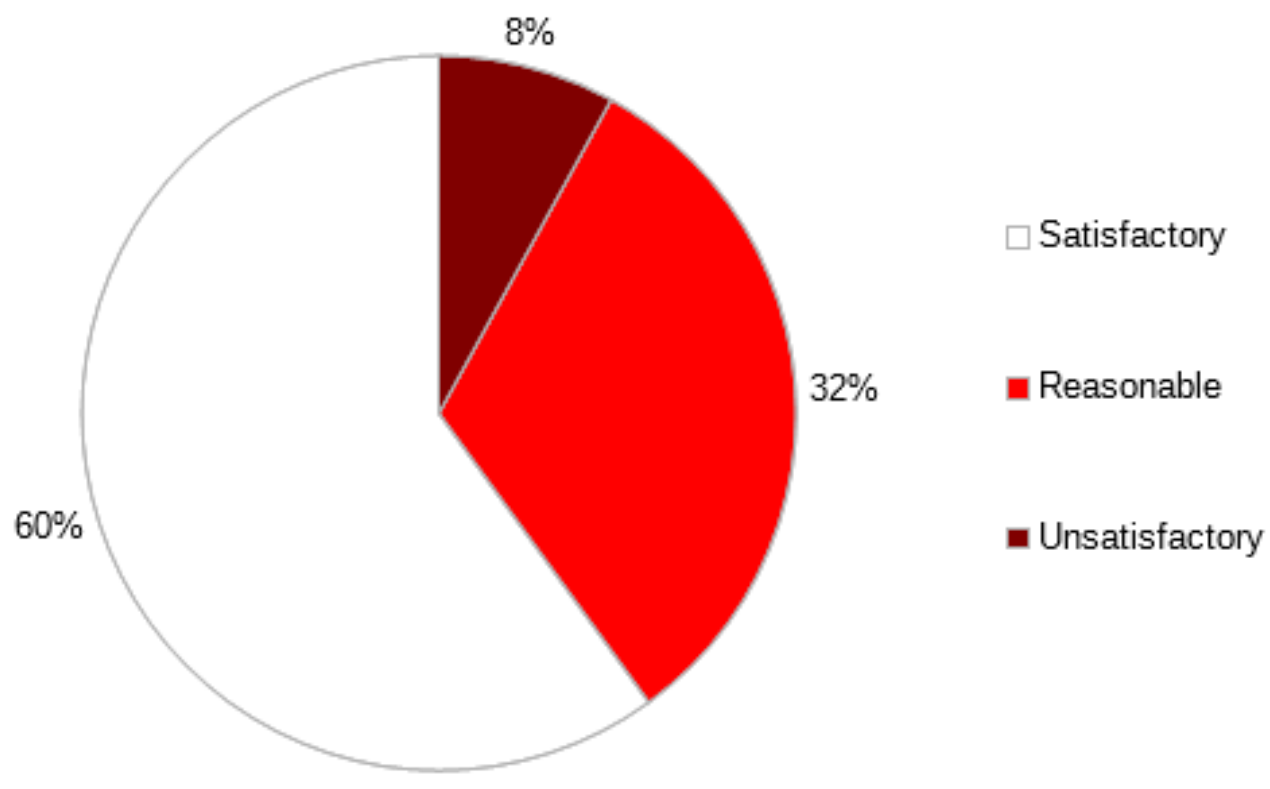

Graphic 6. Physical space/organization.

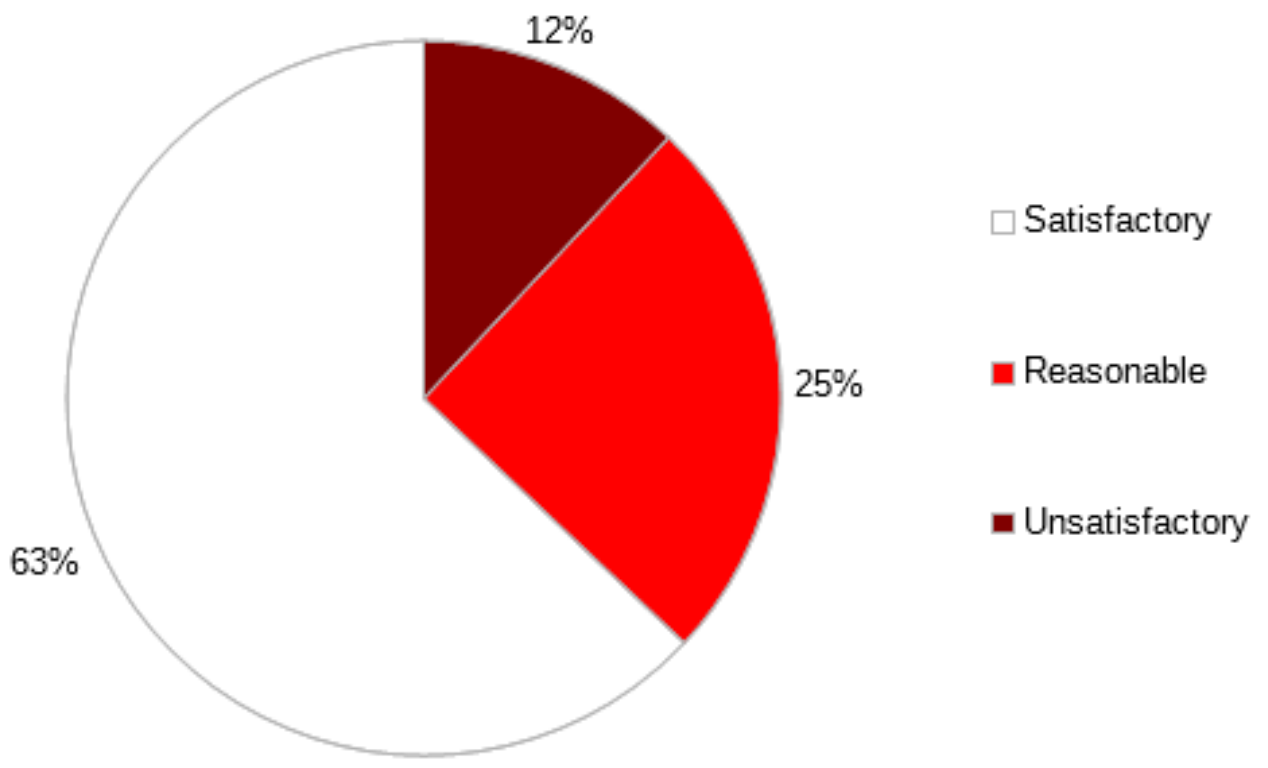

Graphic 7. Self-assessment of the students. 


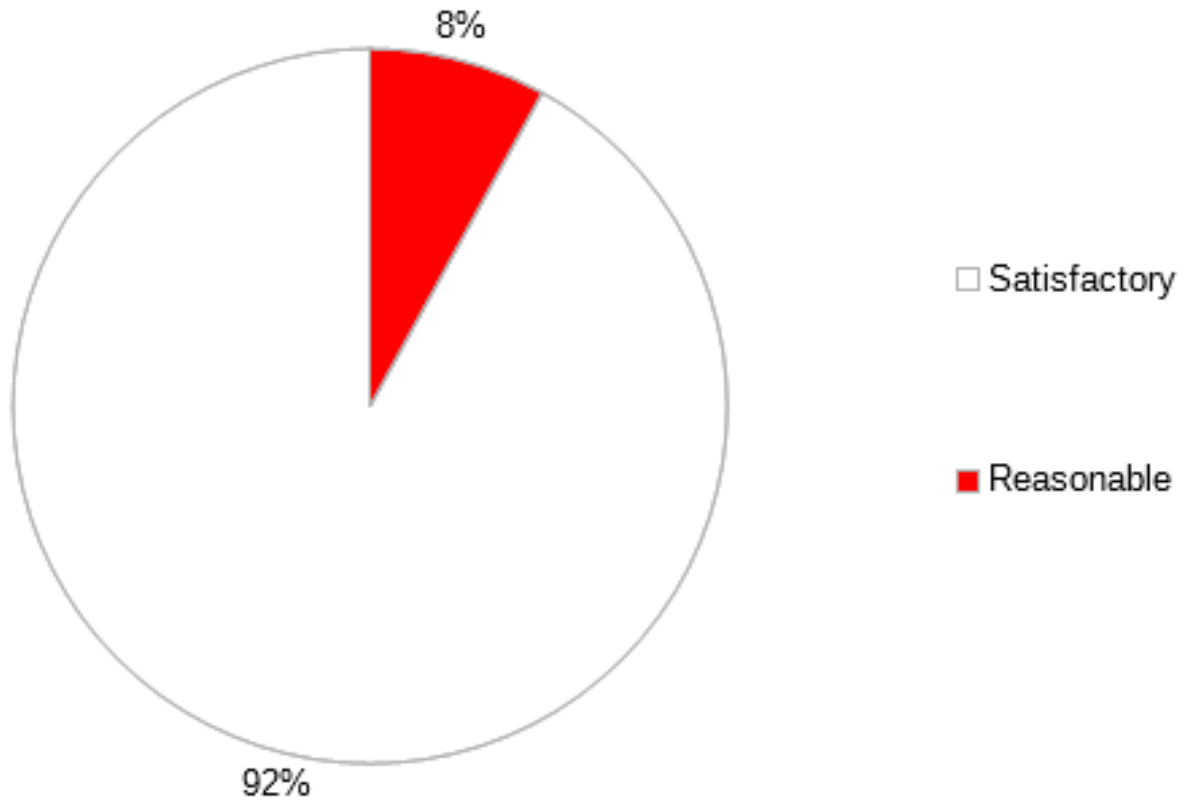

Graphic 8. Group assessment.

\section{Conclusions}

The Cooperative Learning Cell Methodology for Android application development has proven to be effective in bringing students together by providing the learning through the interaction of a group of people. The student had the opportunity to reflect the possibilities through Engineering and the development of applications through the Android programming, in this way the student can attribute new directions to the graduation in Engineering and its areas of action, which can improve the chances of a greater engagement in the activities. Thus, establishing the students interest in the job market and future academic projects.

\section{Acknowledgment}

We would like to acknowledge the Universidade Federal do Ceará, Sobral campus, for providing the space for the accomplishment of the work, the computer laboratory. Also for the coordination of the courses of Computer Engineering and Electrical Engineering.

\section{Reference}

1. VEIGA, I. P. A. Projeto Político da Escola: uma construção coletiva. in VEIGA, I. P. A. Projeto Político Pedagógico: uma construção possível, Campinas, SP: Papirus, 1996, p. 13, 15.

2. CNI. Mais da metade dos estudantes abandona cursos de engenharia 2013. 2013. Site. Available in: <http://www.portaldaindustria.com.br/agenciacni/noticias/2013/07/mais-da-metadedos-estudantes-bandona-cursos-de-engenharia/>. Accessed on: 15 June 2017. 
3. BOCK, A. M. B.; FURTADO, O.; TEIXEIRA, M. L. T. Psicologias: uma introdução ao estudo de psicologia. 5. ed. São Paulo: Saraiva, 2002.

4. AlmeidA, A. M. A.; SOUSA, I. B.; VASCONCELOS, F. H.; SILVA, L. P. de S.; ALMEIDA, R. N. de C. Cooperative learning cell for Android application development, in Alive Engineering Education Transforming and Innovating Engineering Education ISBN: 978-85-495-0151-6 - ICAEEdu 2017 International Conference on Alive Engineering Education, Chapter 38, p. 377 - 385, Rio de Janeiro, Brazil, 21-23 June 2017

5. MARLUCE, Desmotivação em Sala de Aula: Um Desafio para os Educadores na Contemporaneidade. 2008. Site. Available in: <http://www.zemoleza.com.br/trabalhoacademico/sociais-aplicadas/psicologia/desmotivacao-em-sala-de-aula-um-desafio-para-oseducadores-na-contemporaneidade/>. Accessed on: 17 June 2017.

6. MAIA, A.; PEREIRA A.; OLIVEIRA, A. Aprendizagem cooperativa e a evasão acadêmica. Periodicos.ufc.br, p. 1, 2016.

7. SMITH, K. A.; WALLER, A. Cooperative Learning for New College Teachers, University of Minnesota 1997, pp 6-7.

8. LUNELLI, A.; TREICHEL, A. Recrutamento e seleção: Como fazer uma entrevista? 2008.

9. FELDER, R.; B. SALAMON, A. Summary of the different learning styles. 2008. Site Available in: <https://www.southeastern.edu/admin/ds/resources/links/assets/student-learningstyle-handoutpdf.pdf $>$. Accessed on: 17 June 2017.

10. SOUZA, M.; SILVA, A. O Uso das Redes Sociais, Facebook e Whatsapp, Como Ambientes Virtuais De Aprendizagem No Ensino De Química. 2016. Site Available in: $<$ http://www.abq.org.br/cbq/2016/trabalhos/6/9678-17820.html $>$. Accessed on: 17 June 2017.

11. WIKIPEDIA. Parity (mathematics) Site. Available in: $<$ https://en.wikipedia.org/wiki/Parity _(mathematics) >. Accessed on: 19 June 2017. 
